THE effects of various lipoxygenase metabolites of arachidonic acid (AA) were investigated on the growth of freshly isolated human bone marrow monon uclear cells and $m$ arrow stromal cell cultures. LTB $_{4}$, LXA $_{4}$, LXB $_{4}, 12$-HETE and 15-HETE $(1 \mu \mathrm{M})$ decreased $\left[{ }^{3} \mathrm{H}\right]$-thymidine incorporation on marrow stromal cell cultures without affecting cell number. Only 12-HETE showed a dose-response effect on $\left[{ }^{3} \mathrm{H}\right]$-thymidine incorporation. While $\operatorname{LTB}_{4} \quad(1 \mu \mathrm{M})$ decreased thymidine incorporation on marrow mononuclear cells, LTC 4 , LXA $4, \mathrm{LXB}_{4}, 12$-HETE and 15-HETE had no effect. The lipoxygenase inhibitor NDGA had no effect on both cell types suggesting no role of endogenous lipoxygenase metabolites on cell growth. These results suggest no important role of lipoxygenase metabolites of AA on the proliferation of human marrow mononuclear cells and marrow stromal cell cultures.

Key words: Lipoxin, Hydroxyeicosatetraenoic acid, Leukotriene, Marrow stromal cells, Prolife ration

\section{Effects of lipoxygenase metabolites of arachidonic acid on the growth of human mononuclear marrow cells and marrow stromal cell cultures}

\author{
V. Desplat, F. Dupuis, F. Trimoreau, C. Dulery, \\ V. Praloran and Y. Denizot ${ }^{\mathrm{CA}}$
}

Laboratoire d'Hématologie Expérimentale, Faculté de Médecine, 2 rue Dr. Marcland, 87025 Limoges, France

${ }^{\mathrm{CA}}$ Corresponding author

Fax: (+33) 0555435801 and (+33) 0555435866

\section{Introduction}

Human bone marrow stromal cells regulate haematopoiesis by interacting directly with marrow haematopoietic progenitors and/or by releasing cytokines. ${ }^{1,2}$ Lipoxygenase metabolites of arachidonic acid (AA) such as leukotriene $\mathrm{B}_{4}\left(\mathrm{LTB}_{4}\right), \mathrm{LTC}_{4}$, lipoxin $\mathrm{A}_{4}$ $\left(\mathrm{LXA}_{4}\right), \quad \mathrm{LXB}_{4}, \quad$ 12-hydroxyeicosate traenoic acid (12-HETE), and 15-HETE are produced by human marrow mononuclear cells. ${ }^{3,4}$ Several of these AA metabolites act on the grow th of human myeloid and erythroid progenitors in semi-solid culture medium..$^{5-7}$ At this time no study has reported the role of AA metabolites on the grow th of human marrow stromal cells. These results could be of interest since the lipidic compound platelet-activating factor (PAF) stimulates $\left[{ }^{3} \mathrm{H}\right]$-thymidine incorporation in marrow stromal cell cultures. ${ }^{8}$ In this study we have assessed the effect of $\mathrm{LTB}_{4}, \mathrm{LTC}_{4}, \mathrm{LXA}_{4}, \mathrm{LXB}_{4}, 12-\mathrm{HETE}$, 15-HETE, and of the lipoxygenase inhibitor nordihydroguaiaretic acid (NDGA) on the growth of human marrow stromal cell cultures and fresh human mononuclear marrow cells.

\section{Materials and methods}

\section{Cell cultures}

These experiments were performed according to the Helsinki recommendations. Bone marrow sternal cells were harvested from untreated patients referred for diagnosis. Cells collected by aspiration into heparinized tubes were isolated by separation on a Ficoll gradient $(400 \times g, 20 \mathrm{~min})$, and washed twice with Hanks's balanced salts solution. Mononuclear marrow cells were used when the cell morphology was normal.

Cultures of human bone marrow stromal cells (mostly fibroblast-like cells) were established from marrow mononuclear cells seeded in $75 \mathrm{~cm}^{2}$ culture flasks in RPMI 1640 with $20 \%$ fetal calf serum (FCS) (Gibco, Cergy Pontoise, France), penicillin (100 U/ml) and streptomycin $(100 \mu \mathrm{g} / \mathrm{ml})$ (culture medium) at $37^{\circ} \mathrm{C}$ in $5 \% \mathrm{CO}_{2}$ in air as previously described. ${ }^{9}$ After one week, non-adherent cells were removed from culture flasks. Adherent cells were grown to confluence for 4-5 weeks with weekly changes of medium and were subcultured after trypsin treatment $(0.05 \%$ trypsin for $5 \mathrm{~min})$. The cells used in these experiments were at the first passage. In these experimental conditions more than $99.8 \%$ of cells were $\mathrm{CD}_{2}^{-}$and $\mathrm{CD} 22^{-}$indicating the absence of $\mathrm{T}$ and B-cells on the layers and $4 \%$ of cells were $\mathrm{CD} 14^{+}$ and $\mathrm{CD}_{3} 3^{+}$indicating a monocytic/macrophagic lineage. ${ }^{10,11}$

\section{Cell proliferation}

Freshly isolated marrow mononuclear cells $\left(1 \times 10^{5}\right)$ were grow $n$ in $100 \mu \mathrm{l}$ of IMDM with $10 \%$ FCS. $\mathrm{LTB}_{4}$, LTC 4 , LXA $4, \quad \mathrm{LXB}_{4}$, 12-HETE, 15-HETE (Tebu, Le Perray-en-Yvelines, France), NDGA (Sigma, Saint 
Table 1. Effects of lipoxygenase AA metabolites on $\left[{ }^{3} \mathrm{H}\right]$-thymidine incorporation of human bone marrow stromal cells. Experiments were made with stromal cell cultures from 30 donors. Results (in dpm) are the mean \pm SEM from six independent experiments in sixplicate $(n=6)$

\begin{tabular}{|c|c|c|c|c|c|c|c|}
\hline Stimuli & Controls & $1 \mu \mathrm{M}$ & $100 \mathrm{nM}$ & $10 \mathrm{nM}$ & $1 \mathrm{nM}$ & $100 \mathrm{pM}$ & $10 \mathrm{pM}$ \\
\hline $\begin{array}{l}\mathrm{LTB}_{4} \\
\mathrm{LTC}_{4} \\
\mathrm{LXA}_{4} \\
\mathrm{LXB}_{4} \\
\text { 12-HETE } \\
\text { 15-HETE }\end{array}$ & $\begin{array}{l}2625 \pm 522 \\
2950 \pm 550 \\
2577 \pm 350 \\
2508 \pm 399 \\
2413 \pm 225 \\
1859 \pm 172\end{array}$ & $\begin{aligned} 2142 & \pm 542^{* *} \\
3132 & \pm 638 \\
1776 & \pm 242^{* *} \\
1730 & \pm 283^{* *} \\
524 & \pm 44^{* *} \\
1170 & \pm 111^{* *}\end{aligned}$ & $\begin{array}{l}2788 \pm 467 \\
3151 \pm 506 \\
2785 \pm 364 \\
2634 \pm 421 \\
1577 \pm 183^{* *} \\
1753 \pm 213\end{array}$ & $\begin{array}{l}3008 \pm 736 \\
3167 \pm 520 \\
2603 \pm 363 \\
2221 \pm 327 \\
1731 \pm 180^{* *} \\
1642 \pm 190\end{array}$ & $\begin{array}{l}2831 \pm 673 \\
2961 \pm 533 \\
2785 \pm 417 \\
2541 \pm 382 \\
1944 \pm 208^{*} \\
1699 \pm 195\end{array}$ & $\begin{array}{l}2632 \pm 605 \\
2905 \pm 430 \\
2785 \pm 417 \\
2017 \pm 367 \\
1789 \pm 196^{*} \\
1532 \pm 179\end{array}$ & $\begin{array}{l}2718 \pm 547 \\
2526 \pm 319 \\
2570 \pm 393 \\
2575 \pm 479 \\
2057 \pm 243 \\
2398 \pm 280\end{array}$ \\
\hline
\end{tabular}

${ }^{* *} P<0.001,{ }^{*} P<0.01$ (Wilcoxon test) compared with control values

Quentin Fallavier, France) or the appropriate vehicle $(10 \mu \mathrm{l} 2 \%$ of human serum albumin) were added at the start of the culture. Trypsinized marrow stromal cells $\left(1 \times 10^{4}\right.$ per well $)$ were plated for 24 hours in 96-well plates in $100 \mu \mathrm{l}$ of culture medium. Adherent cells were washed with HBSS and $200 \mu \mathrm{l}$ of serum-free medium was added to each well for 2 days. Adherent cells were reactivated with $100 \mu 1$ of RPMI 1640 with $5 \%$ FCS. The various compounds were added immediately after reactivation. After $60 \mathrm{~h}$ of growth, all cultures (in sixplicate $(n=6)$ samples) were pulsed for $12 \mathrm{~h}$ with $1 \mu \mathrm{Gi} / \mathrm{ml}\left[{ }^{3} \mathrm{H}\right]$-thymidine (Amersham, Les Ulis, France) and the cells were harvested using a Skatron cell harvester. Results (in dpm) were compared by Wilcoxon test.

In a separate set of experiments, human marrow stromal cells (in triplicate samples) were harvested after trypsin treatment $(0.05 \%$ trypsin for $5 \mathrm{~min}$ at $37^{\circ} \mathrm{C}$ ) and counted by using a haemocytometer. Results (in cell number) were compared by MannWhitney $U$-test.

\section{Results}

All these experiments were done with bone marrow cells from 47 different donors. Previous experiments showed that FCS increased in a dose-dependent manner $\left[{ }^{3} \mathrm{H}\right]$-thymidine incorporation by stromal cells with $5 \%$ as suboptimal FCS concentration. ${ }^{2}$

As reported in Table 1 , the addition of $\mathrm{LTB}_{4}, \mathrm{LXA}_{4}$, $\mathrm{LXB}_{4}, 12$-HETE and 15-HETE $(1 \mu \mathrm{M})$ significantly $(P<$ $0.001)$ decreased $\left[{ }^{3} \mathrm{H}\right]$-thymidine incorporation by cells cultured with 5\% FCS. $\mathrm{LTB}_{4}, \mathrm{LXA}_{4}, \mathrm{LXB}_{4}$, 12-HETE and 15-HETE inhibited by $19 \pm 8 \%, 24 \pm 10 \%$ $22 \pm 6 \% 74 \pm 6 \%$ and $37 \pm 4 \%\left[{ }^{3} \mathrm{H}\right]$-thymidine incorporation, respectively. Except for 12-HETE, no dose-response curve was found. LTC $_{4}$ had no effect on thymidine incorporation. As reported in Table 2, despite a significant effect on $\left[{ }^{3} \mathrm{H}\right]$-thymidine incorporation no significant effect was found on the number of marrow stromal cells after 3 days of growth with the different AA metabolites $(1 \mu \mathrm{M})$. Finally the lipoxygenase inhibitor NDGA $(1 \mu \mathrm{M})$ had no significant $(P>0.05$, six independent experi- ments) effect on the $\left[{ }^{3} \mathrm{H}\right]$-thymidine incorporation of stromal cell cultures $(3493 \pm 1871 \mathrm{dpm}$ vs $2664 \pm$ $1372 \mathrm{dpm}$ for NDGA-treated cells and control cells, respectively).

As reported in Table 3, only $\mathrm{LTB}_{4}$ had a significant effect on the $\left[{ }^{3} \mathrm{H}\right]$-thymidine incorporation of freshly isolated human marrow mononuclear cells. NDGA $(1 \mu \mathrm{M})$ had no effect $(P>0.05$, four experiments) on their thymidine incorporation $(90326 \pm 9262 \mathrm{dpm}$ vs. $81712 \pm 8532 \mathrm{dpm}$ for NDGA-treated cells and control cells, respectively).

\section{Discussion}

Studies have reported the positive or negative effects of lipoxygenase metabolites of AA on cell proliferation. Thus, 12-HETE and 15-HETE stimulate $\left[{ }^{3} \mathrm{H}\right]$-thymidine incorporation in mammary tumour cells, ${ }^{12}$ and endothelial cells, ${ }^{13}$ but inhibit it in neuroblastoma cell cultures. ${ }^{14} \mathrm{LTB}_{4}$ and $\mathrm{LTC}_{4}$ stimulate DNA synthesis in cultured arterial smooth muscle cells, ${ }^{15}$ while 12-HETE decreases the grow th of aortic smooth muscle cells. ${ }^{16}$ These latter results are of interest since bone marrow stromal cells share numerous phenotypic similarities with vascular smooth muscle cells. ${ }^{17}$

The growth of fresh marrow mononuclear cells is not affected by lipoxygenase metabolites of AA.

Table 2. Effects of lipoxygenase metabolites of AA on human marrow stromal cell number. Cell number was determined after 3 days of growth with AA metabolites $(1 \mu \mathrm{M})$. Results (in $1 \times 10^{3}$ cells) are reported as mean \pm SEM of four independent experiments in triplicate

Cell number $\left(\times 10^{3}\right) \quad$ Statistical significance

\begin{tabular}{lll}
\hline Controls & $6.6 \pm 0.5$ & \\
LTB $_{4}$ & $4.9 \pm 0.7$ & $P=0.38$ \\
LXA $_{4}$ & $6.3 \pm 0.7$ & $P=0.77$ \\
LXB $_{4}$ & $5.0 \pm 0.5$ & $P=0.14$ \\
12-HETE & $5.6 \pm 0.7$ & $P=0.53$ \\
15-HETE & $5.6 \pm 0.6$ & $P=0.46$ \\
\hline
\end{tabular}

Statistical significance was determined by Mann-Whitney $U_{\text {-test }}$ as compared with control values. 
Table 3. Effects of lipoxygenase AA metabolites on $\left[{ }^{3} \mathrm{H}\right]$-thymidine incorporation of freshly isolated human mononuclear bone marrow cells. Experiments were made with marrow cells from 14 donors. Results (in dpm) are the mean \pm SEM from four independent experiments in sixplicate $(n=6)$

\begin{tabular}{lclllll}
\hline Stimuli & \multicolumn{1}{c}{ Controls } & \multicolumn{1}{c}{$1 \mu \mathrm{M}$} & \multicolumn{1}{c}{$100 \mathrm{nM}$} & $10 \mathrm{nM}$ & $1 \mathrm{nM}$ & $100 \mathrm{pM}$ \\
\hline LTB $_{4}$ & $58499 \pm 9276$ & $46780 \pm 11243^{*}$ & $61661 \pm 13177$ & $66545 \pm 11617$ & $66075 \pm 11169$ & $63568 \pm 10476$ \\
LTC $_{4}$ & $69415 \pm 6558$ & $64311 \pm 7881$ & $74968 \pm 8451$ & $70270 \pm 7475$ & $73999 \pm 10340$ & $71075 \pm 8278$ \\
LXA $_{4}$ & $57227 \pm 12448$ & $54848 \pm 13025$ & $54362 \pm 11939$ & $64290 \pm 15259$ & $58318 \pm 13514$ & $51295 \pm 11268$ \\
LXB $_{4}$ & $100218 \pm 13485$ & $95781 \pm 12384$ & $94208 \pm 12468$ & $87635 \pm 11725$ & $83321 \pm 11639$ & $80401 \pm 12070$ \\
12-HETE & $73871 \pm 10048$ & $69283 \pm 10318$ & $73732 \pm 8534$ & $73157 \pm 10490$ & $73050 \pm 9269$ & $76918 \pm 10998$ \\
15-HETE & $77168 \pm 9008$ & $73956 \pm 8742$ & $75191 \pm 8449$ & $80799 \pm 10372$ & $81043 \pm 8788$ & $77516 \pm 8635$ \\
\hline
\end{tabular}

${ }^{*} P<0.01$ Wilcoxon test.

Although statistically significant, the small decrease of incorporation of thymidine with $\mathrm{LTB}_{4}$ brings some doubts on its physiological meaning. Micromolar concentrations of $\mathrm{LTB}_{4}, \mathrm{LXA}_{4}, \mathrm{LXB}_{4}$ and $15-\mathrm{HETE}$ decrease $\left[{ }^{3} \mathrm{H}\right]$-thymidine incorporation in human bone marrow stromal cell cultures. However the fact that no dose-response curve was found and that no effect was documented on cell number cast some doubts on the physiological meaning of the observed effects on thymidine incorporation. In contrast to the other AA metabolites, 12-HETE inhibits in a dosedependent manner thymidine incorporation in marrow stromal cell cultures. However no effect was found on cell counts. An explanation might be that $\left[{ }^{3} \mathrm{H}\right]$-thymidine incorporation is not only an index of cell proliferation but may also reflect intracellular events other than cell division such as diffusion of DNA precursors. ${ }^{18}$ Another explanation for these results might be that only a small percentage of cells were proliferating and that cell counts were not sensitive enough to detect changes.

Taken together our results suggest no important role of exogenous lipoxygenase metabolites of AA in the grow th of human bone marrow stromal cells and mononuclear marrow cells in vitro. Moreover results with NDGA suggest that endogenous lipoxygenase metabolites had no role on FCS-induced cell growth. These results markedly differ from data showing that PAF stimulates $\left[{ }^{3} \mathrm{H}\right]$-thymidine incorporation in freshly isolated human mononuclear marrow cells, ${ }^{19}$ and marrow stromal cell cultures. ${ }^{8}$

\section{References}

1. Mayani H, Guilbert LJ, Janowska-Wieczorek A. Biology of the hemopoietic microenvironment. Eur J Haematol 1992; 49: 225-233.

2. Rougier F, Dupuis F, Denizot Y. Human bone marrow fibroblasts - an overview of their characterization, proliferation and inflammatory mediator production. Hematol Cell Ther 1996; 38: 241-246.

3. Stenke L, Laurén L, Reizenstein P, Lindgren JA. Leukotriene production by fresh human bone marrow cells: evidence of altered lipoxygenase activity in chronic myelocytic leukemia. Exp Hematol 1987; 15: 203-207.

4. Stenke L, Mansour M, Edenius C, Reizenstein P, Lindgren JA. Formation and proliferative effects of lipoxins in human bone marrow. Biochem Biophys Res Commun 1991; 180: 255-261.
5. Claesson HE, Dahlberg N, Gahrton G. Stimulation of human myelopoies is by leukotriene $\mathrm{B}_{4}$. Biochem Biophys Res Commun 1985; 131: 579-585.

6. Miller AM, Weiner RS, Ziboh VA. Evidence for the role of leukotrienes C4 and D4 as essential intermediates in CSF-stimulated human myeloid colony formation. Exp Hematol 1986; 14: 760-765.

7. Snyder DS, Desforges JF. Lipoxygenase metabolites of arachidonic acid modulate hematopoiesis. Blood 1986; 67: 1675-1679.

8. Rougier F, Dupuis F, Cornu E, Dulery C, Praloran V, Denizot Y. Plateletactivating factor and antagonists modulate DNA synthesis in human bone marrow stromal cell cultures. J Lipid Me diators Cell Signalling 1997; 16: $147-153$.

9. Denizot Y, Rougier F, Dupuis F, Verger C, Dulery C, Laskar M, Aldigier JC, Praloran V. PAF and haematopoiesis. VIII. Biosynthes is and metabolism of platelet-activating factor by human bone marrow stromal cells. Exp Hematol 1996; 24: 1327-1332.

10. Rougier F, Cornu E, Gachard N, Praloran V, Denizot Y. Tumor necrosis factor-alpha (TNF- $\alpha)$ stimulates the grow th of human bone marrow stromal cells. Med Inflamm 1997; 6: 233-235.

11. Fixe P, Rougier F, Ostyn E, Gachard N, Faucher JL, Praloran V, Denizot Y. Spontaneous and inducible production of macrophage colony-stimulating factor by human bone marrow stromal cells. Eur Cytokine Netw 1997; 8: 91-95.

12. Lee PPH, Ip MM Regulation of proliferation of rat mammary tumor cells by inhibitors of cyclooxygenase and lipoxygenase. Prostagland Leuk Essent Fatty 1992; 45: 21-31.

13. Setty BNY, Graeber JE, Stuart MJ. The mitogenic effect of 15- and 12 hydroxyeicosatetraenoic acid on endothelial cells may be mediated via diacylglycerol kinase inhibition. I Biol Chem 1987; 262: $17613-17622$

14. Werner EJ, Walenga RW, Dubowy RL, Boone S, Stuart MJ. Inhibition of human malignant neuroblastoma cell DNA synthesis by lipoxygenase metabolites of arachidonic acid. Cancer Res 1985; 45: 561-563.

15. Palmberg L, Lindgren JA, Thyberg J, Claesson HE. On the mechanism of induction of DNA synthesis in cultured arterial smooth muscle cells by leukotrienes. Possible role of prostaglandin endoperoxide synthase products and platelet-derived growth factor. J Cell Sci 1991; 98: 141-149.

16. Smith DL, Willis AL, Mahmud I. Eicosanoid effects on cell proliferation in vitro: relevance to atherosclerosis. Prostaglandins Leukotrienes Med 1984; 16: 1-10.

17. Galmiche MC, Koteliansky VE, Brière J, Hervé P, Charbord P. Stromal cells from human long-term marrow cultures are mesenchymal cells that differentiate following a vascular smooth muscle differentiation pathway. Blood 1993; 82: 66-76.

18. Bazill GW, Dexter TM Platelet-activating factor antagonist L-652,731 inhibits thymidine transport. Biochem Pharmacol 1989; 38: 373-374.

19. Denizot Y, Dupuis F, Trimoreau F, Verger C, Allegraud A, Praloran V. PAF and haematopoiesis: IX. Platelet-activating factor increases DNA synthesis in human bone marrow cells. J Lipid Mediators Cell Signalling 1996; 15: $1-4$.

ACKNOWLEDGMENTS. The authors are grateful to the 'Ligue Nationale Contre le Cancer' (Comité de la Corrèze et de la Creuse) and the 'Conseil Régional du Limousin' for funding our project. F. Dupuis is the recipient of a grant from the Association pour la Recherche sur le Cancer (ARC). This paper is the first of a series: Arachidonic acid metabolites and haematopoiesis.

Received 27 October 1997; accepted 31 October 1997 


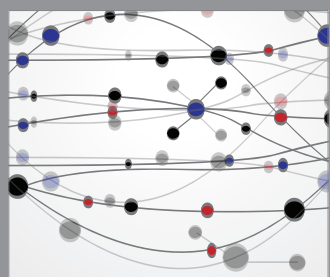

The Scientific World Journal
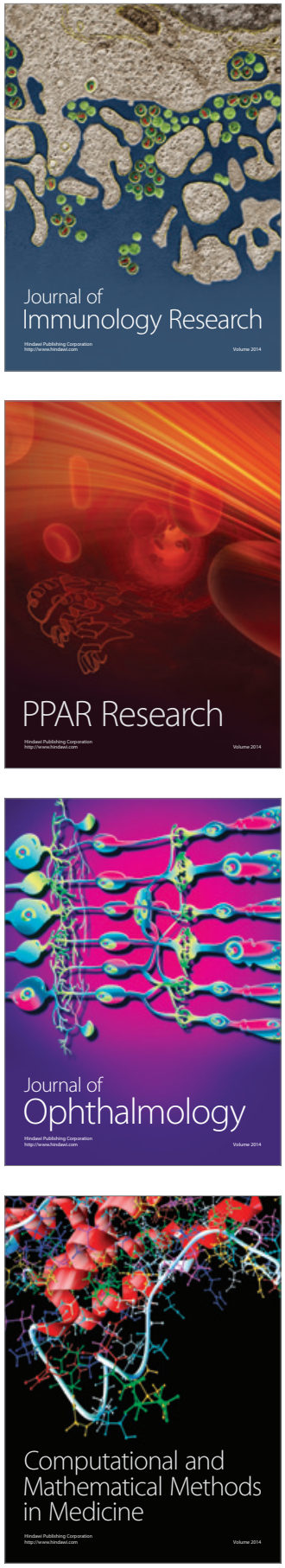

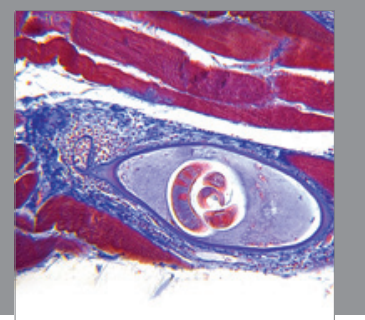

Gastroenterology

Research and Practice
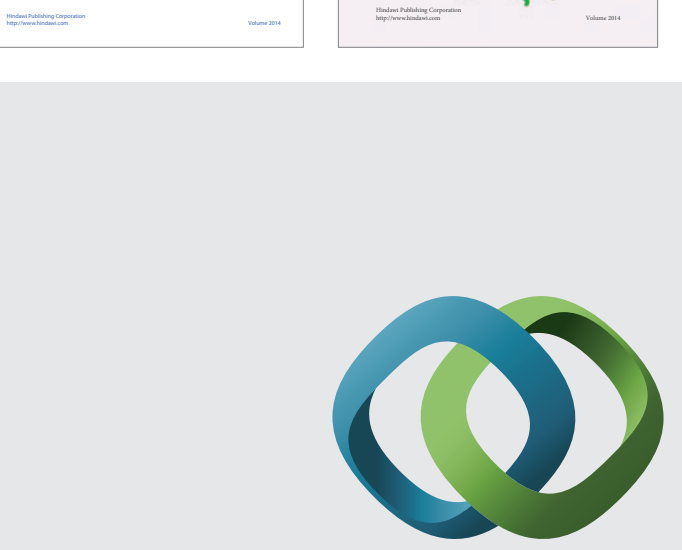

\section{Hindawi}

Submit your manuscripts at

http://www.hindawi.com
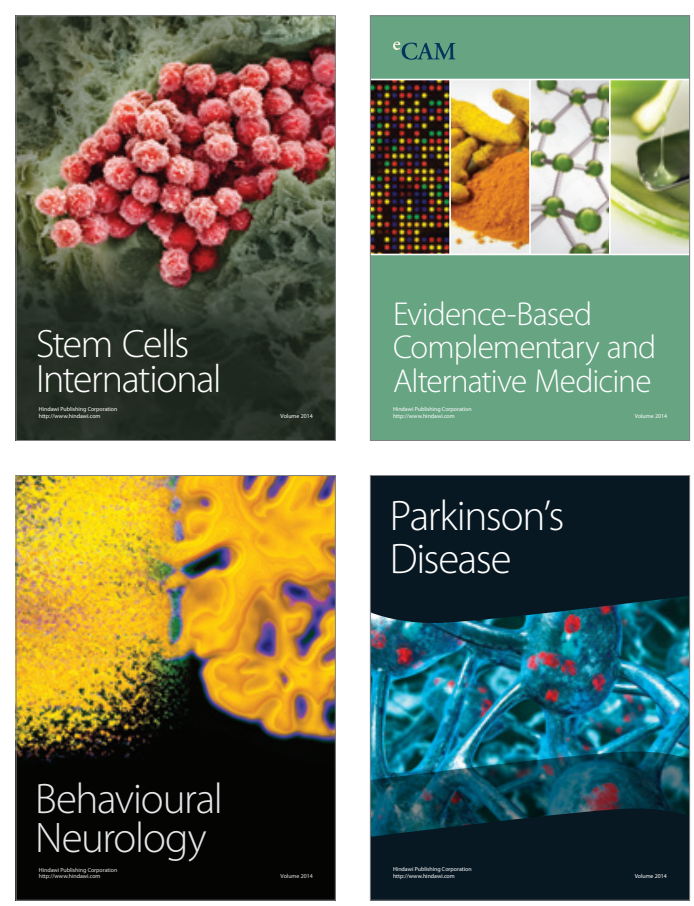

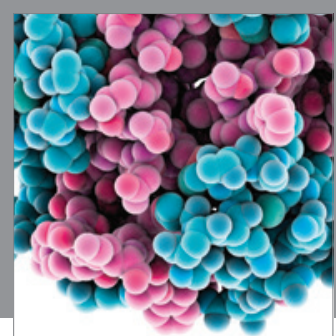

Journal of
Diabetes Research

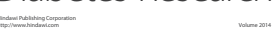

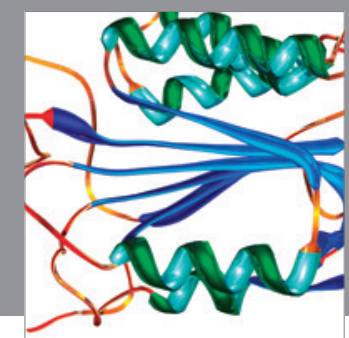

Disease Markers
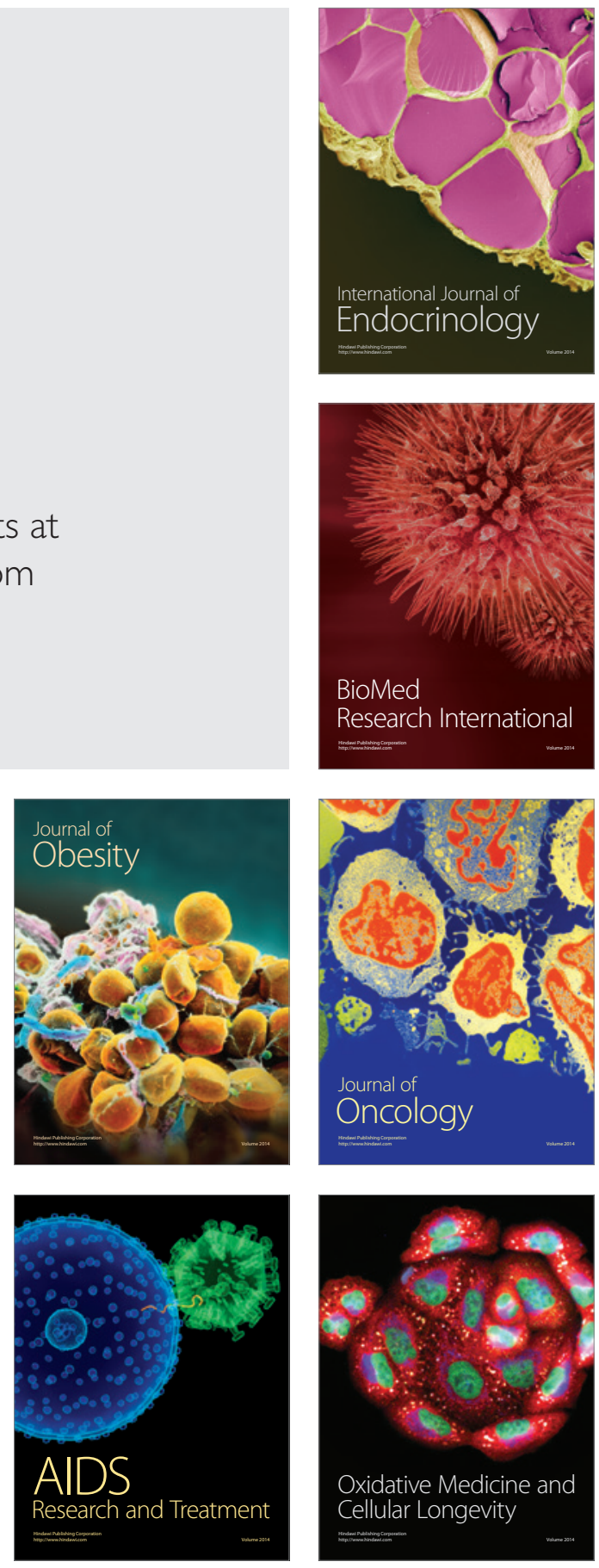